\title{
Negative Exponent
}

National Cancer Institute

\section{Source}

National Cancer Institute. Negative Exponent. NCI Thesaurus. Code C161821.

How many times to divide by a number. 